\title{
Relationships between rainfall and groundwater recharge in seasonally humid Benin: a comparative analysis of long-term hydrographs in sedimentary and crystalline aquifers
}

\author{
D. O. Valerie Kotchoni ${ }^{1,2,3} \cdot$ Jean-Michel Vouillamoz ${ }^{2} \cdot$ Fabrice M. A. Lawson $^{1,2,3} \cdot$ Philippe Adjomayi $^{4}$. \\ Moussa Boukari ${ }^{1} \cdot$ Richard G. Taylor $^{5}$
}

Received: 29 June 2017 / Accepted: 4 May 2018 / Published online: 8 June 2018

(C) The Author(s) 2018

\begin{abstract}
Groundwater is a vital source of freshwater throughout the tropics enabling access to safe water for domestic, agricultural and industrial purposes close to the point of demand. The sustainability of groundwater withdrawals is controlled, in part, by groundwater recharge, yet the conversion of rainfall into recharge remains inadequately understood, particularly in the tropics. This study examines a rare set of 19-25-year records of observed groundwater levels and rainfall under humid conditions (mean rainfall is $\sim 1,200 \mathrm{~mm}_{\text {year }}{ }^{-1}$ ) in three common geological environments of Benin and other parts of West Africa: Quaternary sands, Mio-Pliocene sandstone, and crystalline rocks. Recharge is estimated from groundwater-level fluctuations and employs values of specific yield derived from magnetic resonance soundings. Recharge is observed to occur seasonally and linearly in response to rainfall exceeding an apparent threshold of between 140 and $250 \mathrm{~mm} \mathrm{year}^{-1}$. Inter-annual changes in groundwater storage correlate well to inter-annual rainfall variability. However, recharge varies substantially depending upon the geological environment: annual recharge to shallow aquifers of Quaternary sands amounts to as much as $40 \%$ of annual rainfall, whereas in deeper aquifers of Mio-Pliocene sandstone and weathered crystalline rocks, annual fractions of rainfall generating recharge are 13 and 4\%, respectively. Differences are primarily attributed to the thickness of the unsaturated zone and to the lithological controls on the transmission and storage of rain-fed recharge.
\end{abstract}

Keywords Groundwater recharge/water budget $\cdot$ Benin $\cdot$ Sub-Saharan Africa $\cdot$ Hydrograph

\section{Introduction}

Groundwater is the primary source of water for domestic and agricultural water supplies throughout the tropics and much of

This article is part of the topical collection "Determining groundwater sustainability from long-term piezometry in Sub-Saharan Africa"

D. O. Valerie Kotchoni

valerie.kotchoni@ird.fr

1 University of Abomey-Calavi, National Institute of water, Abomey-Calavi, Benin

2 IRD, University Grenoble Alpes, CNRS, Grenoble INP, IGE, F-38000 Grenoble, France

3 International Chair in Mathematical Physics and Applications (ICMPA - UNESCO CHAIR), Cotonou, Benin

4 Direction Générale de l'Eau, Cotonou, Benin

5 Department of Geography, University College London, London, UK
Sub-Saharan Africa (Döll et al. 2012). Efforts to meet projected increases in freshwater demand over the next few decades across Sub-Saharan Africa depend on development of the groundwater resource, which in many environments is the only perennial source of freshwater (MacDonald et al. 2012). The sustainability of current and future groundwater abstraction relies on groundwater recharge but the conversion of rainfall into recharge remains poorly understood. This gap in knowledge is due primarily to the limited availability of sustained observations of changes in groundwater storage in this region (Taylor et al. 2013). Studies based on rare piezometric observations and stable-isotope ratios indicate that intensive rainfall events contribute preferentially to groundwater recharge in the tropics (Taylor and Howard 1999; Owor et al. 2009; Taylor et al. 2013; Jasechko and Taylor 2015) but the role played by the unsaturated zone in transmitting water remains unclear (e.g. infiltration pathways and controls). Further, most studies which quantify recharge from groundwater-level fluctuations in Sub-Sahara Africa are constrained by 
uncertainty in coefficients (e.g. specific yield) of groundwater storage (e.g. Sibanda et al. 2009; Obuobie et al. 2012).

In Benin, previous assessments of recharge are rare and have relied primarily on the use of soil-moisture balance models for which there is substantial uncertainty in their parameterisation due to a lack of field observations. For example, studies in the Mio-Pliocene sediments of southern Benin have estimated recharge using very different parameterisations that have generated outcomes which are both uncertain and differ substantially: 50 to $104 \mathrm{~mm}$ year $^{-1}$ (Totin 2010) versus $266 \mathrm{~mm} \mathrm{year}^{-1}$ (Achidi et al. 2012a). Application of the same unconstrained soil-moisture balance model to weathered crystalline aquifers in central Benin produces recharge estimates ranging from 250 to $300 \mathrm{~mm}$ year $^{-1}$ (Achidi et al. 2012b) which differ from previous estimates generated from the use of the water-table fluctuation method (i.e. $74-370 \mathrm{~mm}$ year $^{-1}$ and 106 to $208 \mathrm{~mm}$ year $^{-1}$, Kamagaté et al. 2007 and Séguis et al. 2011 respectively). These latter estimates are, however, based on groundwater-level records of very limited duration (i.e. 2 and 4 years) and are unconstrained by local measurements of specific yield. In summary, substantial uncertainty remains in the estimation of recharge in Benin as assessments are inconsistent and inadequately constrained by observations.

In this study, long-term (19-25 years) records of groundwater levels and rainfall are used to explore the relationships between rainfall and recharge in three hydrogeological environments common to the humid tropics of Benin and other parts of West Africa: Quaternary unconsolidated sediments, Mio-Pliocene sandstone, and weathered-fissured Neoproterozoic crystalline rocks. Further, the study marks a substantial improvement on previous analyses of recharge using the water-table fluctuation method in Sub-Saharan Africa as it not only employs multi-decadal piezometric records but also employs specific yield values constrained by magnetic resonance sounding (MRS) experiments carried out at each of the sites featuring long-term "chronicles" of groundwater storage changes.

\section{Materials and methods}

\section{Monitoring sites}

The geology of Benin is composed of two principal domains that are common in West Africa. Northern and central regions are dominated by crystalline rocks whereas the southern region consists of a coastal sedimentary basin with rocks from Cretaceous to recent ages (Fig. 1). A network of piezometers was established in the 1990s in sedimentary formations in southern Benin by the University of Abomey Calavi and the
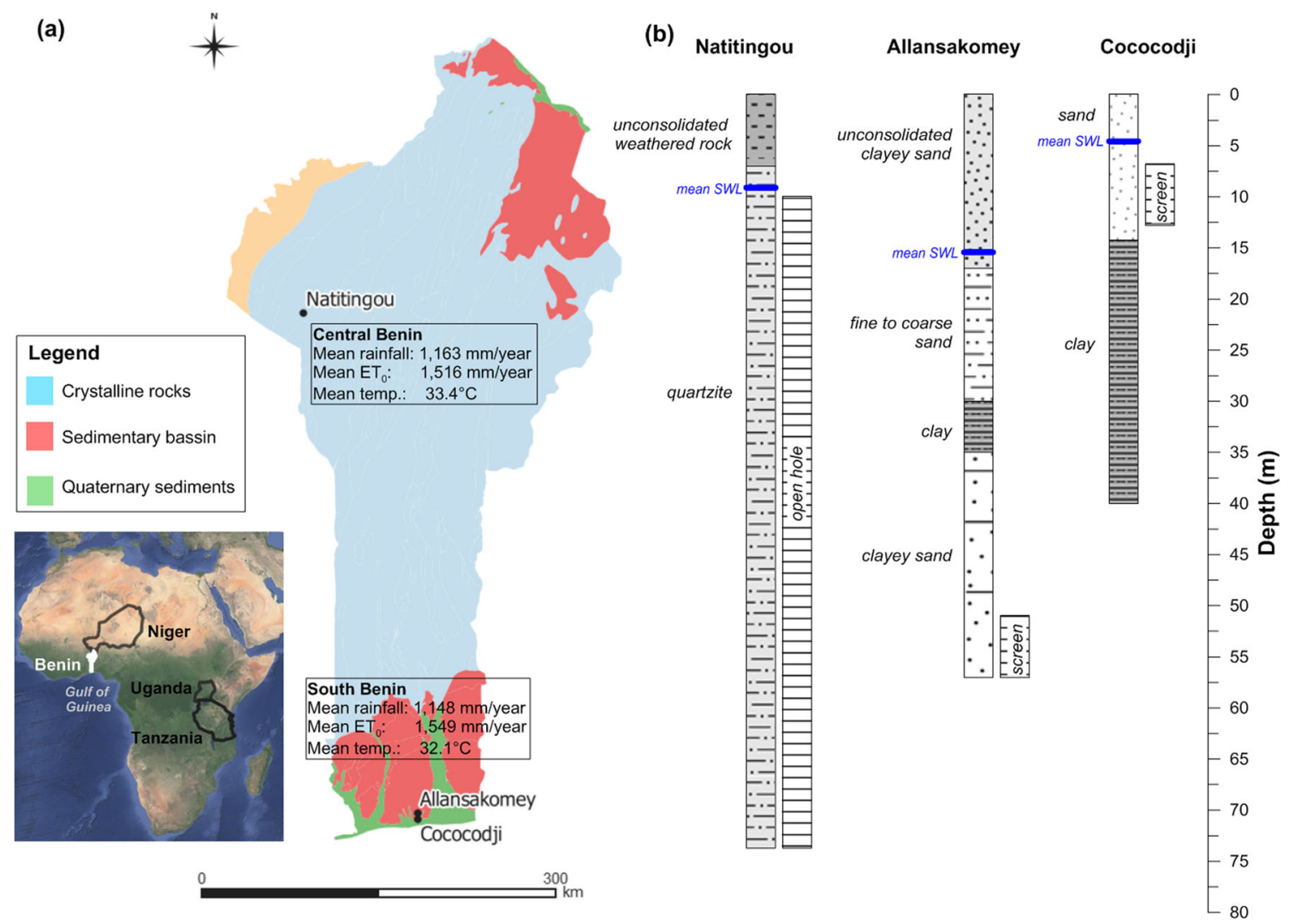

Fig. 1 Monitoring sites. a Map of Africa with enlarged view of a simplified geological map of Benin and mean (1980-2009) climate data (modified from Achidi et al. 2012a). b Simplified lithology of monitored piezometers as per borehole reports 
national society in charge of the water supply of cities (SONEB). More recently, a national network of groundwater monitoring sites was established by the National Directorate of Water (Direction Générale de l'Eau, DG-Eau) in the Ministry of Energy, Oil and Water.

To examine the relationship between rainfall and recharge, monitoring sites with short record duration (i.e. less than 15 years) and excessive gaps in their records were excluded. Three monitoring sites were selected in hydrogeological environments that commonly supply groundwater to inhabitants of Benin and that are common in West Africa: Quaternary sediments at Cococodji; Mio-Pliocene sediments at Allansakomey; and crystalline rocks at Natitingou (Fig. 1). These monitoring sites are appropriate to examine recharge because: (1) monitored water-table depths (WTD) are impacted by neither abstraction nor constructed surfaces; (2) records of WTD are some of the longest available in Benin; and (3) rain gauges are localised in the vicinity of the piezometer. At each piezometer, WTDs have been measured manually since the 1990s (Table 1). Recordings have been carried out by technicians of the DG-Eau and the University of AbomeyCalavi using an electrical probe (i.e. "dipper"). The timestep of the measurements in these long-term records varies from 8 to 22 days on average (Fig. 2).

Strong seasonality is observed in groundwater-level fluctuations in monitored aquifers in all three geological contexts and reflects the seasonally humid climates of each monitoring site (Fig. 2). In the south (i.e. Cococodji and Allansakomey sites), rainfall usually occurs between March and October. Mean annual temperature, rainfall and Penman-Monteith reference evapotranspiration $\left(\mathrm{ET}_{0}\right)$ obtained at three weather stations located in southern Benin between 1980 and 2009 are $32{ }^{\circ} \mathrm{C}, 1,148$ and $1,549 \mathrm{~mm}$, respectively (Achidi et al. 2012a). In central Benin (Natitingou site), the rainy season is slightly shorter (April to October); mean annual rainfall $(1,163 \mathrm{~mm})$, mean air temperature $\left(33{ }^{\circ} \mathrm{C}\right)$ and $\mathrm{ET}_{0}$ $\left(1,516 \mathrm{~mm} \mathrm{year}^{-1}\right)$ measured at two weather stations for the 1980-2009 period are very similar to that recorded in southern Benin (Achidi et al. 2012a). All sites are situated on surfaces of low relief with mean slopes based on Shuttle Radar Topography Mission data of $1.4 \%$ (standard deviation $\sigma=0.5 \%$ ), $1.2 \%$ $(\sigma=0.4 \%)$ and $2 \%(\sigma=1.9 \%)$ at Cococodji, Allansakomey and Natitingou, respectively. All three monitoring sites are in suburban areas that are relatively unaffected by constructed surfaces (i.e. tarmac, concrete) and where soils primarily derive from the underlying geology.

\section{Recharge calculation and groundwater level modelling}

Recharge was calculated based on the observed groundwaterlevel fluctuation (e.g. Scanlon et al. 2002; Healy and Cook 2002; Sibanda et al. 2009; Obuobie et al. 2012; Jassas and Merkel 2014). The water-table fluctuation Method (WTFM) assumes that change in groundwater level is controlled by the balance of recharge $R\left[\mathrm{LT}^{-1}\right]$ to drainage $D\left[\mathrm{LT}^{-1}\right]$ :

$R_{t}=S_{\mathrm{y}} \cdot \frac{\Delta_{h}}{\Delta_{t}}+D_{t}$

where $S_{\mathrm{y}}[-]$ is the specific yield and $\Delta h$ represents the change in groundwater level [L] through time $\Delta t[\mathrm{~T}]$. To solve Eq. (1), $S_{\mathrm{y}}$ has been estimated from measurements using magnetic resonance sounding (see next section), whereas $D_{t}$ is estimated based on observed recessions in groundwater levels during dry seasons (i.e. when no rain has occurred over multiple weeks). Recharge $R_{t}$ was first calculated at a daily time step by linearly interpolating the observed change in groundwater level $\Delta h$; monthly and yearly recharge were calculated by summing daily recharge. Relationships between rainfall and recharge were assessed on monthly and annual time steps through the use of regression plots. To assess the influence of daily rainfall on recharge, relationships between rainfall and recharge were systematically assessed by applying a threshold daily rainfall for generating recharge from 1 to $30 \mathrm{~mm}$ in increments of $1 \mathrm{~mm}$. Observed relationships $R_{t}=f\left(\right.$ rainfall $_{t}$ ) were then used to model a daily time series of groundwater level as:

$h_{t}=h_{t-\Delta t}+\frac{R_{t}-D_{t}}{S_{\mathrm{y}}}$

Time-lags between rainfall and recharge (ranging from 0 to 50 days) were then applied to model the time series of

Table 1 Physical characteristics of monitoring sites in Benin

\begin{tabular}{|c|c|c|c|c|c|c|c|c|c|}
\hline \multirow[t]{2}{*}{ Piezometer } & \multicolumn{2}{|c|}{ Monitoring period } & \multirow{2}{*}{$\begin{array}{l}\text { Mean time-step } \\
\text { (days) }\end{array}$} & \multirow{2}{*}{$\begin{array}{l}\text { Distance to } \\
\text { rain gauge } \\
\text { (m) }\end{array}$} & \multicolumn{2}{|c|}{$\begin{array}{l}\text { Screen depth below } \\
\text { ground surface }\end{array}$} & \multirow[t]{2}{*}{ Lithology } & \multicolumn{2}{|c|}{ Water-table depth } \\
\hline & from & to & & & from $(\mathrm{m})$ & to $(\mathrm{m})$ & & $\max (\operatorname{mbgl})$ & $\min (\mathrm{mbgl})$ \\
\hline Cococodji & 03/07/1991 & $09 / 04 / 2015$ & 8 & 7,100 & -6.8 & -12.8 & Unconsolidated sands & 6.39 & 1.74 \\
\hline Allansakomey & $04 / 08 / 1994$ & $10 / 23 / 2015$ & 22 & 6,900 & -51 & -57 & Sandstone & 16.53 & 13.03 \\
\hline Natitingou & 05/21/1997 & $07 / 27 / 2015$ & 9 & 3,800 & -10 & -73.7 & Crystalline rock (quartzites) & 14.37 & 3.2 \\
\hline
\end{tabular}

$\mathrm{mbgl}$ metres below ground level 

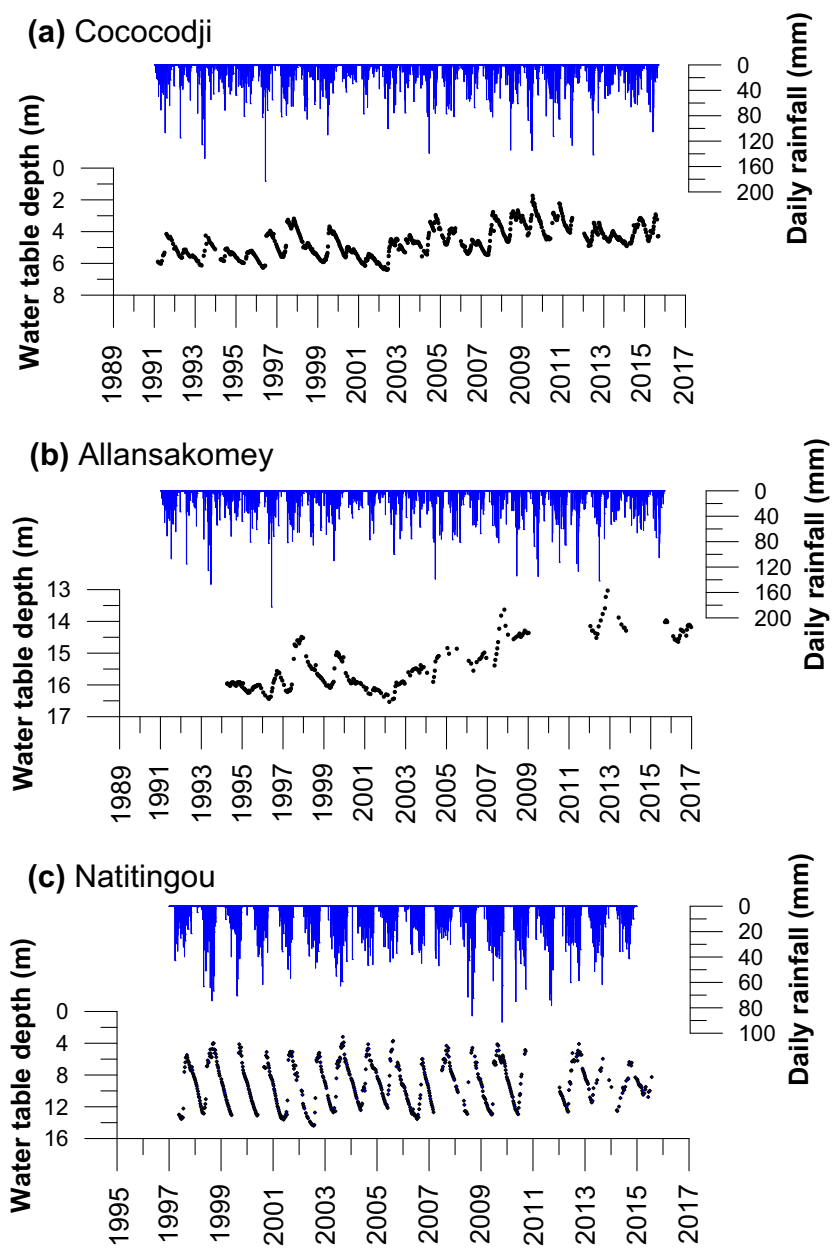

Fig. 2 Groundwater-level fluctuations and rainfall records. a Cococodji b Allansakomey c Natitingou

groundwater levels; the degree to which the modelled time series represented the observed time series was assessed using the Normalised Root-Mean-Square Error (NRMSE) and the Nash-Sutcliffe Coefficient (NSC):

$$
\begin{aligned}
& \text { NRMSE }=\frac{\text { RMSE }}{\overline{h_{\text {observed }}} \text { with RMSE }} \\
&=\sqrt{\frac{\sum_{i=1}^{n}\left(h_{\text {observed }, i}-h_{\text {modelled }, i}\right)^{2}}{n}} \\
& \text { NSC }=1-\frac{\sum_{i=1}^{n}\left(h_{\text {observed }, i}-h_{\text {modelled }, i}\right)^{2}}{\sum_{i=1}^{n}\left(h_{\text {observed }, i}-\overline{h_{\text {observed }}}\right)^{2}}
\end{aligned}
$$

The influence of rainfall on recharge was assessed with the use of annual standard score of rainfall and recharge:

Standard score $=\frac{x-\bar{x}}{\sigma}$ where $x$ is the rainfall or the recharge, $\bar{x}$ and $\sigma$ are the mean and the standard deviation of the population respectively.

\section{Estimation of specific yield}

Estimation of $S_{\mathrm{y}}$ at each of three monitoring stations with long-term groundwater-level records (Fig. 1) was conducted through MRS (Vouillamoz et al. 2012a, 2014). Detailed descriptions of the MRS technique can be found in numerous publications (e.g. Legchenko and Valla 2002; Legchenko 2013). The major advantage of MRS compared to other geophysical methods (e.g. electrical resistivity tomography) is the direct measurement of signals that are generated by subsurface water itself. One of the primary output parameters obtained from the interpretation of MRS measurements is the variation in depth of the MRS water content $\theta_{\text {MRS }}$. MRS measurements were conducted at the 3 monitoring sites and $S_{\mathrm{y}}$ was calculated using relationships between $\theta_{\mathrm{MRS}}$ and $S_{\mathrm{y}}$ established in previous studies carried out in several sites of the same geological environment (Table 2). The relationship used to calculate the specific yield in crystalline rock was established in central Benin (at six locations) where the Natitingou site is also located (Vouillamoz et al. 2014). For the monitoring site in Mio-Pliocene sandstone at Allansakomey the relationship used to calculate specific yield was established in the neighbouring Niger at six locations (Boucher et al. 2009) and is expected to be valid for Benin as the geological context is comparable. At Cococodji, the specific yield of Quaternary sands was estimated to be equal to the MRS water content as established in similar beach sands in India (Vouillamoz et al. 2012b). Applied $S_{\mathrm{y}}$ values for Quaternary sands, Mio-Pliocene sandstones and crystalline rocks are $16.2 \%, 7.1$ and $0.4 \%$ respectively (Table 2 ); the low value of $S_{\mathrm{y}}$ obtained at Natitingou is consistent with observations that this quartzite aquifer possesses a very low specific capacity $\left(0.3 \mathrm{~m}^{2}\right.$ day $\left.^{-1}\right)$. Uncertainty in $S_{\mathrm{y}}$ is estimated from uncertainties in MRS output parameters that are calculated by determining the range of acceptable solutions (i.e. equivalence analysis).

\section{Results}

\section{Estimation of recharge}

Recharge rates at the three long-term monitoring sites in Benin were calculated using Eq. (1) and values of specific yield derived from MRS water content (Table 2). Calculated recharge varies substantially in magnitude from $491 \mathrm{~mm}$ year $^{-1}$ (standard deviation $\sigma=160 \mathrm{~mm}$ year $^{-1}$ ) on average in shallow Quaternary sands (41\% of mean annual rainfall), to $148 \mathrm{~mm}$ year $^{-1}\left(\sigma=55 \mathrm{~mm}\right.$ year $\left.^{-1}\right)$ in Mio-Pliocene sandstones (12\% of mean annual rainfall), and $51 \mathrm{~mm} \mathrm{year}^{-1}$ 
Table 2 Specific yield calculation with the use of MRS water content

\begin{tabular}{llllll}
\hline Piezometer & Rocks & $S_{\mathrm{y}}$ calculation & Reference & $\theta_{\text {MRS }}(\%)$ & $S_{\mathrm{y}}$ mean/uncertainty $(\%)$ \\
\hline Cococodji & Quaternary sands & $S_{\mathrm{y}}=\theta_{\text {MRS }}$ & Vouillamoz et al. 2012b & 16.2 & $16.2 \pm 0.4$ \\
Allansakomey & Mio-Pliocene sandstones & $S_{\mathrm{y}}=0.38 . \theta_{\text {MRS }}$ & Boucher et al. 2009 & 21.3 & $7.1 \pm 0.4$ \\
Natitingou & Quarztites & $S_{\mathrm{y}}=0.53 . \theta_{\text {MRS }}+0.007$ & Vouillamoz et al. 2014 & 0.8 & $0.4 \pm 0.1$ \\
\hline
\end{tabular}

$\left(\sigma=10 \mathrm{~mm}\right.$ year $\left.^{-1}\right)$ in crystalline rocks (4\% of mean annual rainfall, Table 3 ).

Regression plots of recharge against rainfall show clear linear relationships above a threshold between annual rainfall and estimated recharge at all three locations (Fig. 3). Linear relationships are strong (i.e. coefficient of correlation ranging from 0.80 to 0.97 ) and extrapolating these relationships to a recharge value of zero denies potential non-linearities outside of the range of data used to inform them but suggests minimum thresholds in annual rainfall for recharge in the range of $140-250 \mathrm{~mm}$ at each location. The linearity in the relationships between monthly rainfall and estimated monthly recharge is lower due, in part, to time lags between input (rainfall) and response (groundwater-level rise). Finally, removing daily rainfall events of less than 5-15 $\mathrm{mm}$ did not impact the observed relationships between rainfall and recharge (Fig. 4a and Table 4).

Using the observed links between annual recharge and rainfall, the water-table depth (WTD) was estimated on a daily time step using Eq. (2). The calculated WTD was then fitted to the observations by tuning modelled recharge-rainfall relationships and testing time lags between rainfall and recharge (Table 4). No time lag is needed to improve the model of the shallow sandy water table at Cococodji (average WTD is $4.5 \mathrm{~m}$ below ground level, bgl), but time lags of respectively 17 days and 2 days slightly improved the model of the deeper sandstones aquifer at Allansakomey (Fig. 4b, average WTD is $15.4 \mathrm{~m} \mathrm{bgl}$ ) and quartzite at Natitingou (average WTD is $9.1 \mathrm{~m} \mathrm{bgl}$ ) respectively. Interestingly, the refined simple linear relationships explain almost all the fluctuation in the water table fluctuation at the three locations (Fig. 5).

\section{Influence of rainfall on groundwater storage}

Standardized recharge and rainfall time series demonstrate a clear relationship between rainfall and recharge at all three locations (Fig. 6). Annual recharge is higher (or lower) than the mean value when annual rainfall is also higher (or lower) than the mean rainfall (Fig. 6a). This trend is confirmed by the observed relationships between the annual groundwater storage balance (i.e. the difference in storage between January and December the same year) and the annual rainfall (Fig. 6b). Currently, changes in groundwater storage are strongly correlated to rainfall at the three locations (correlation coefficient of $0.91,0.8$ and 0.96 for Cococodji, Allansakomey and Natitingou respectively). When annual rainfall is below the mean value, the annual storage balance is negative (i.e. groundwater storage declines), whereas the annual storage balance is positive (i.e. groundwater storage rises) when the annual rainfall is higher than the mean value.

\section{Discussion}

\section{Uncertainty in recharge analysed using the WTFM}

Application of the water-table fluctuation method (WTFM) to each of the three long-term piezometric records in Benin demonstrates considerable ability $(\mathrm{NSC}=0.66$ to 0.85$)$ to explain multi-decadal variations in groundwater levels in three different hydrogeological environments with varying water-table depths (Table 4). The WTFM method is nonetheless a simplification of a complex set of processes by which water moves to, and from, the water table. It is thus desirable to apply the WTFM in combination with other methods (e.g. Misstear et al. 2009; Sibanda et al. 2009) and on-going research currently seeks to test the outcomes here with evidence from hydrochemistry, stable-isotope ratios of $\mathrm{O}$ and $\mathrm{H}$, and hydrological models in order to assess more widely recharge in the main geological units
Table 3 Annual rainfall and calculated recharge

\begin{tabular}{|c|c|c|c|c|c|c|c|}
\hline \multirow[t]{2}{*}{ Piezometer } & \multicolumn{3}{|c|}{ Annual rainfall $(\mathrm{mm})$} & \multicolumn{3}{|c|}{ Annual recharge $(\mathrm{mm})$} & \multirow{2}{*}{$\begin{array}{l}\text { Mean annual ratio } \\
\text { recharge/rainfall }(\%)\end{array}$} \\
\hline & Min & Mean & $\operatorname{Max}$ & Min & Mean & $\operatorname{Max}$ & \\
\hline Cococodji & 735 & 1189 & 1591 & 180 & 491 & 717 & 41 \\
\hline Allansakomey & 735 & 1229 & 1899 & 49 & 148 & 250 & 12 \\
\hline Natitingou & 850 & 1180 & 1591 & 38 & 51 & 67 & 4 \\
\hline
\end{tabular}


Fig. 3 Relationship between recharge and rainfall at yearly and monthly time steps. a Cococodji; b Allansakomey; c Natitingou (a) Cococodji
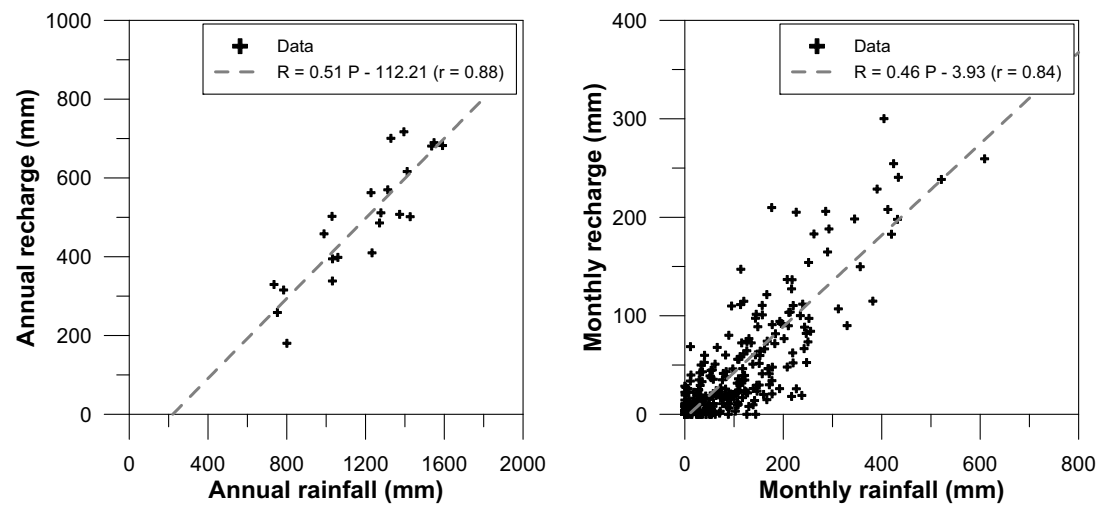

(b) Allansakomey
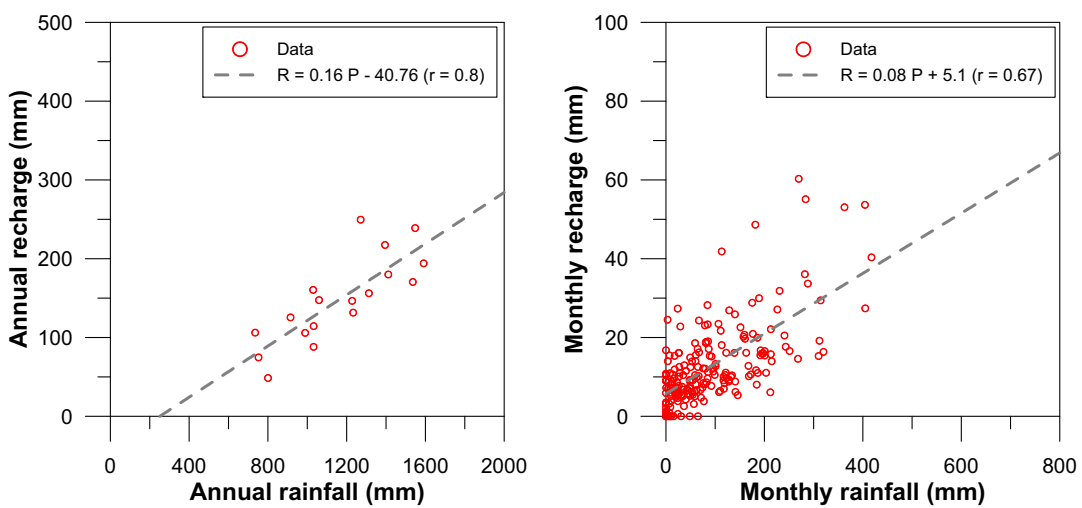

(c) Natitingou

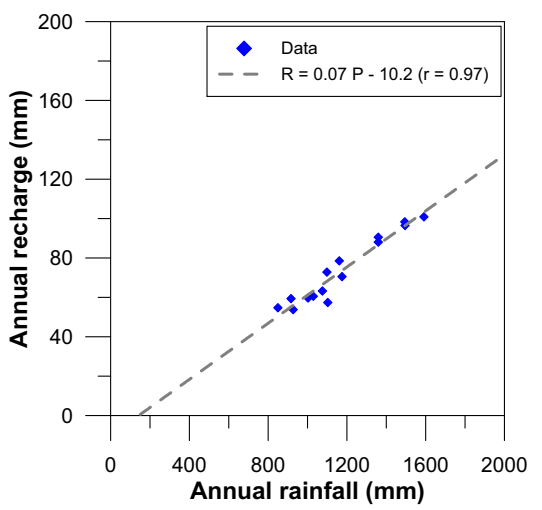

of Benin. Another key uncertainty associated with the use of the WTFM is the representivity of the analysed longterm piezometric data in each monitored aquifer. Figure 7 plots additional piezometric records that exist in each of the three monitored hydrogeological environments, alongside the more complete records analysed in the preceding. The amplitude and seasonality in groundwater levels in each of these additional, though limited, time series mirrors well the dynamics observed in the analysed time series. These additional observations, which range in distance from 12 to $113 \mathrm{~km}$ from the analysed time series, indicate that, at a minimum, the analysed time series are not anomalous.

\section{Magnitude of recharge}

Groundwater recharge estimated from groundwater-level records of 19-25 years in duration from three selected sites in Benin varies substantially in its magnitude from one location to the other (Fig. 8a and Table 3). These differences in estimated recharge ranging from 51 to $491 \mathrm{~mm}_{\text {year }}{ }^{-1}$ cannot be explained by differences in rainfall as mean annual rainfall (MAR) varies by $<5 \%$ among the three locations (Table 3) and differences in daily rainfall intensities are small (Fig. 8b). At Natitingou in central Benin, the magnitude of estimated recharge to the weathered-fissured quartzite aquifer of $\sim 4 \%$ of MAR, is consistent with the lower 

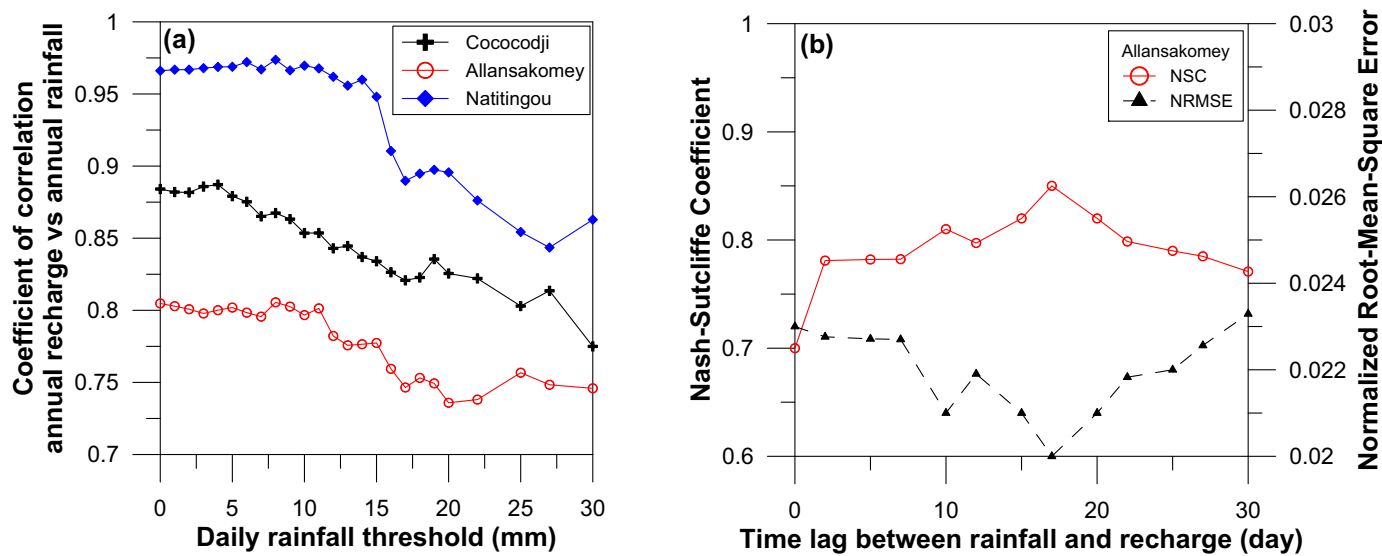

Fig. 4 Outcomes of a sensitivity analysis of the modelled relationships between rainfall and recharge constrained by long-term observations, for a daily rainfall threshold; and $\mathbf{b}$ the lag time between rainfall and recharge at Allansakomey

estimate proposed by Kamagaté et al. (2007; i.e. $\sim 5$ to $24 \%$ of MAR) using just 2 years of piezometric data and an unconstrained $S_{\mathrm{y}}$ value at a site $\sim 60 \mathrm{~km}$ away. This new estimate is, however, far lower than previous, much less well-constrained studies of Séguis et al. (2011) and Achidi et al. (2012b), which estimate recharge is 9-17 and $25 \%$ of MAR, respectively; the latter estimate is included in the new hydrogeological map of Benin and misrepresents the renewability of groundwater in this region. Detailed water-balance studies in central Benin, estimating actual evapotranspiration (AET) from hydrometric and eddy covariance measurements (Séguis et al. 2011; Mamadou et al. 2016), indicate that the bulk of annual rainfall (up to 86 and $72 \%$ respectively) is returned to the atmosphere via evapotranspiration; groundwater discharge is primarily explained by local evapotranspiration. Here stream flow is ephemeral and dominated by contributions from (Hortonian) surface runoff and interflow. The low recharge flux estimated at Natitingou is thus primarily attributed to high AET facilitated by the thick unsaturated (vadose) zone.

In southern Benin, reference evapotranspiration $\left(\mathrm{ET}_{0}\right)$ is similar to northern Benin (see section 'Materials and methods') and stream flow is also predominantly seasonal (Le Barbé et al. 1993). Robust estimates of AET are unavailable. In the shallow aquifer with Quaternary sands at
Cococodji, $\sim 40 \%$ of mean annual rainfall $(\sim 490 \mathrm{~mm})$ is estimated to contribute to recharge through a thin (mean thickness of $4.5 \mathrm{~m}$ ) unsaturated zone for which there is almost no time lag between rainfall and recharge responses (Table 4; Fig. 5). Here the higher recharge flux, the first published estimate for this aquifer, is attributed to reduced surface runoff associated with more transmissive soils and a thin vadose zone facilitating the conversion of infiltrating rainfall to recharge. At Allansakomey, a lower proportion $(\sim 13 \%)$ of annual rainfall is converted to recharge where the unsaturated zone is thicker (mean thickness of $15 \mathrm{~m}$ ) and less permeable due to a higher clay content. The mean $\left(148 \mathrm{~mm} \mathrm{year}^{-1}\right)$ and range $\left(49-250 \mathrm{~mm} \mathrm{year}^{-1}\right)$ in annual recharge are consistent with previously modelled recharge by Totin (2010) ranging from 50 to $104 \mathrm{~mm}$ year $^{-1}$ but substantially less again than that modelled by Achidi et al. (2012b). This revised recharge estimate for the sandstone aquifer at Allansakomey is of importance as this aquifer is the primary source of safe water to the most populated area of Benin. Differences in land use (Favreau et al. 2009; Ibrahim et al. 2014), local relief, and reference evapotranspiration are minor among the three monitoring sites but their collective influences on recharge cannot be discarded to explain, in part, differences in recharge rates estimated from long-term groundwater-level data.
Table 4 Key characteristics of groundwater-level fluctuation models

\begin{tabular}{|c|c|c|c|c|c|}
\hline \multirow[t]{2}{*}{ Piezometer } & \multirow{2}{*}{$\begin{array}{l}\text { Daily modelled rainfall/recharge } \\
\text { relationships }\end{array}$} & \multirow{2}{*}{$\begin{array}{l}\text { Daily rainfall } \\
\text { threshold } \\
(\mathrm{mm})\end{array}$} & \multirow{2}{*}{$\begin{array}{l}\text { Time } \\
\text { lag } \\
\text { (day) }\end{array}$} & \multicolumn{2}{|c|}{ Fit of the model } \\
\hline & & & & $\begin{array}{l}\text { NRMSE } \\
(\%)\end{array}$ & $\begin{array}{l}\text { NSC } \\
(-)\end{array}$ \\
\hline Cococodji & $R=0.41 \cdot P$ & 5 & 0 & 9.5 & 0.78 \\
\hline Allansakomey & $R=0.13 \cdot P$ & 10 & 17 & 2 & 0.85 \\
\hline Natitingou & $R=0.043 \cdot P$ & 15 & 2 & 17 & 0.66 \\
\hline
\end{tabular}

$R$ recharge; $P$ precipitation; NRMSE normalised root-mean-square error; NSC Nash-Sutcliffe coefficient 
Fig. 5 Rainfall and both simulated and observed watertable depth (WTD) time series in Benin at: a Cococodji; b Allansakomey; c Natitingou
Fig. 6 The relationships between rainfall and recharge. a annual standardized index, $\mathbf{b}$ annual groundwater storage balance. Note the difference in scales for the second $y$-axis (b)

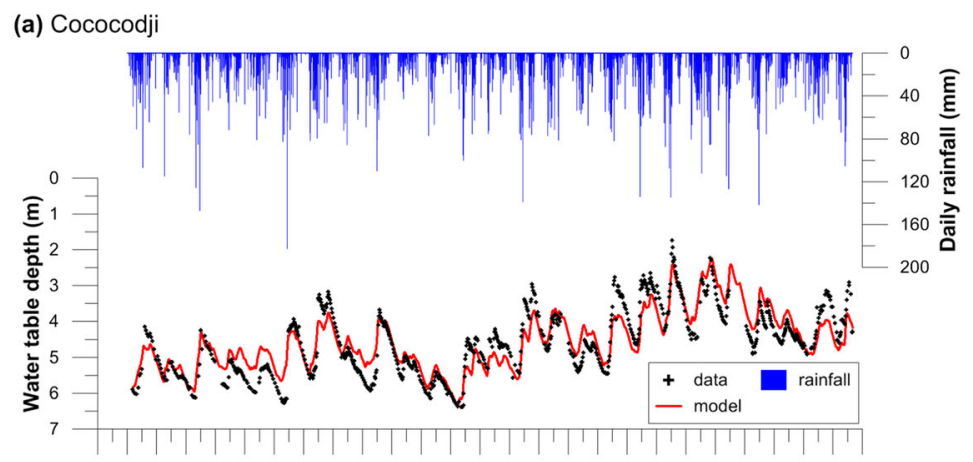

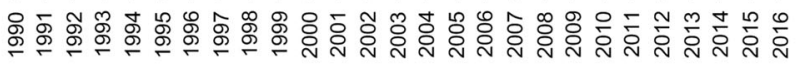

(b) Allansakomey

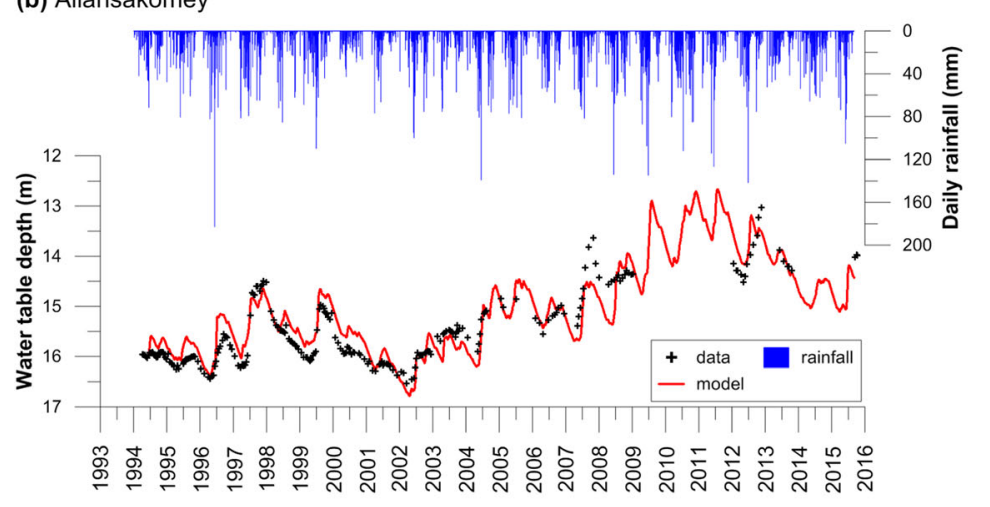

(c) Natitingou

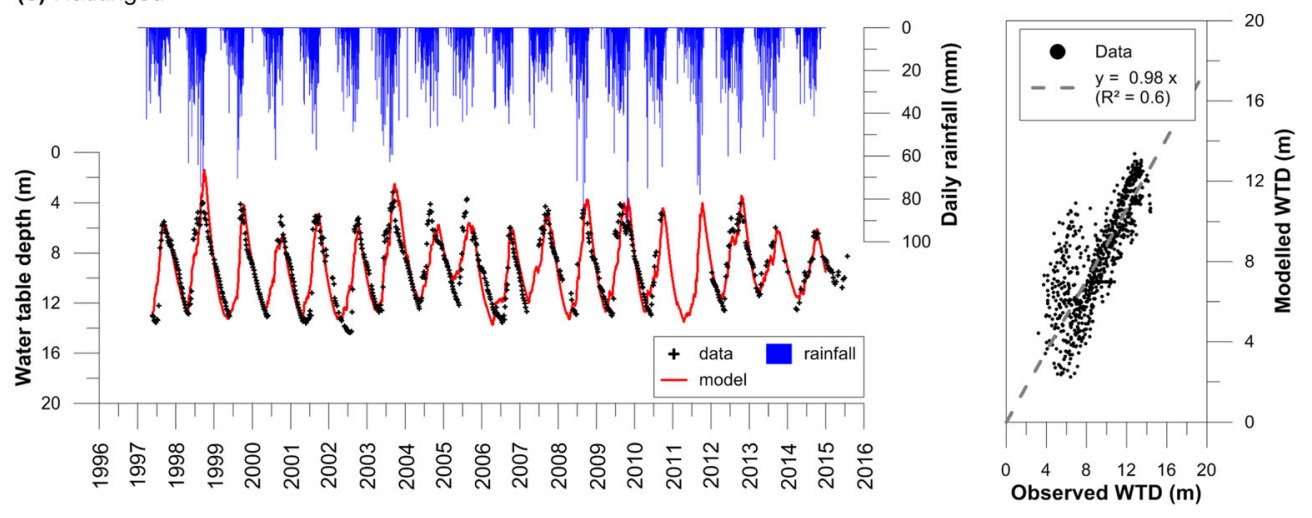

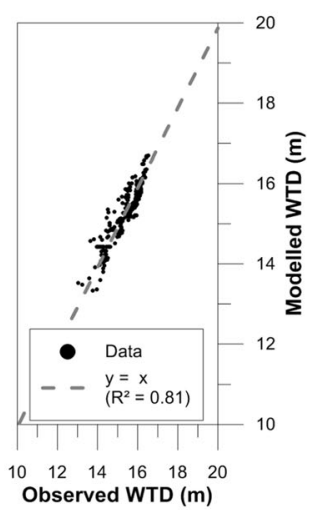

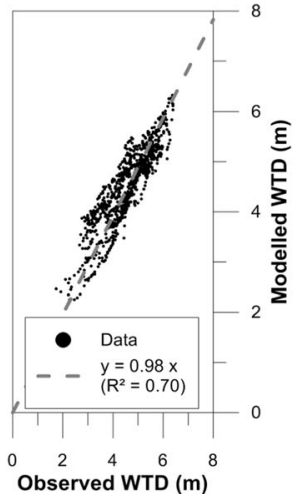

Observed WTD (m)
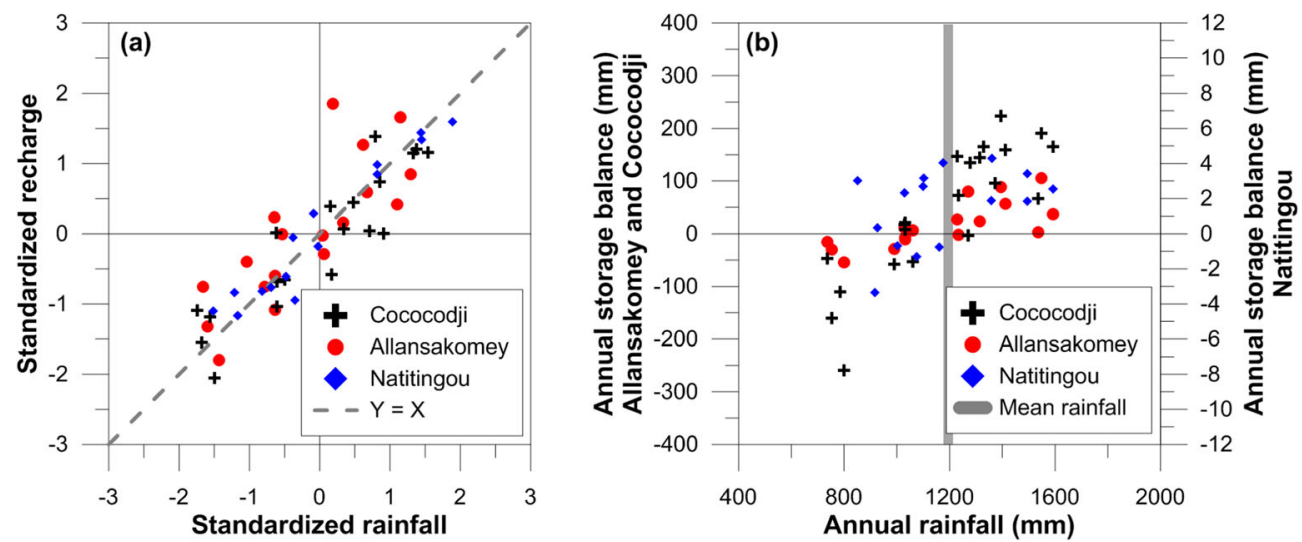
Fig. 7 Comparison of the selected water-table time-series with other chronicles located in the same geological unit

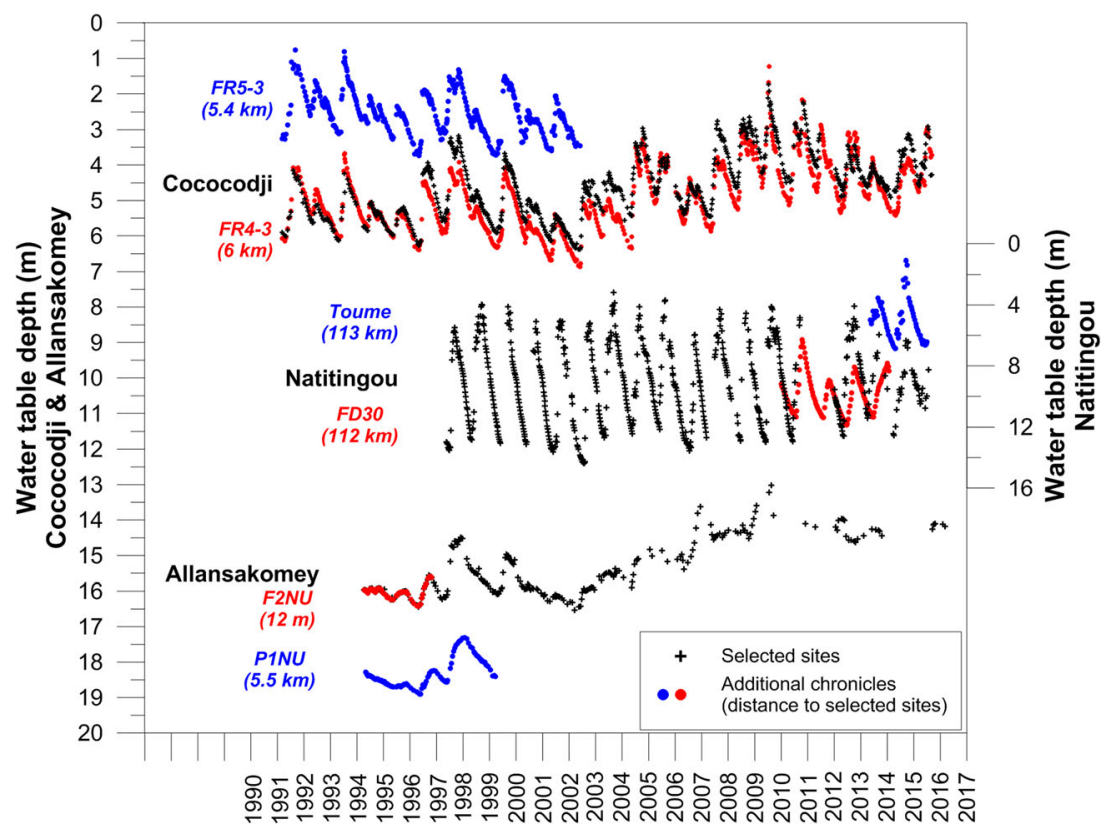

\section{Rainfall/recharge relationships}

Computed groundwater recharge derived from observed groundwater-level time series records in three hydrogeological environments in Benin is strongly correlated ( $r=0.88$ to 0.97 ) to annual rainfall (Fig. 8a). These linear relationships regress to implied thresholds for recharge of 220, 250 and $140 \mathrm{~mm}_{\text {year }}{ }^{-1}$ for Cococodji, Allansakomey and Natitingou respectively. Extrapolating such relationships beyond the range in the data yields highly uncertain conclusions yet these apparent thresholds are consistent with evidence of the relationship between mean annual rainfall and recharge (apparent threshold of $\sim 250 \mathrm{~mm}$ year $^{-1}$ ) compiled from recharge studies across SubSaharan Africa (Bonsor and MacDonald 2010). On a daily time step, application of rainfall thresholds of 5-15 mm day ${ }^{-1}$ was found to best match groundwater fluctuations using Eq. (2) (Table 4). This finding mirrors improved correlations between rainfall exceeding similar daily thresholds (e.g. $10 \mathrm{~mm}^{\text {day }}{ }^{-1}$ ) and recharge that have been observed in Uganda (Owor et al.
2009). The dependence of recharge on rainfall exceeding a threshold is noteworthy, as climate change intensifies rainfall, especially in the tropics (Allan et al. 2010); fewer but heavier rainfall events may consequently serve to enhance recharge. Long-term groundwater-level hydrographs in seasonally humid Benin also indicate that recharge occurs annually but varies substantially, similar to piezometric evidence from seasonally humid Uganda (Owor et al. 2009). This empirical evidence is in contrast to the highly episodic nature of groundwater recharge observed in semi-arid central Tanzania, where recharge is found to occur in just a few years each decade in response to heavy seasonal rainfall associated with the El Niño Southern Oscillation (Taylor et al. 2013).

At monthly time scales, rainfall/recharge relationships deteriorate for deeper water tables at Allansakomey and Natitingou, but remain strong for the shallow water table at Cococodji (Fig. 3). This difference may stem from the effects of the unsaturated zone in transmitting water, which are not represented in the simple WTFM model. Time lags estimated
Fig. 8 Comparison of rainfall and recharge characteristics at three monitoring sites: a annual recharge versus rainfall; $\mathbf{b}$ daily rainfall frequency distribution
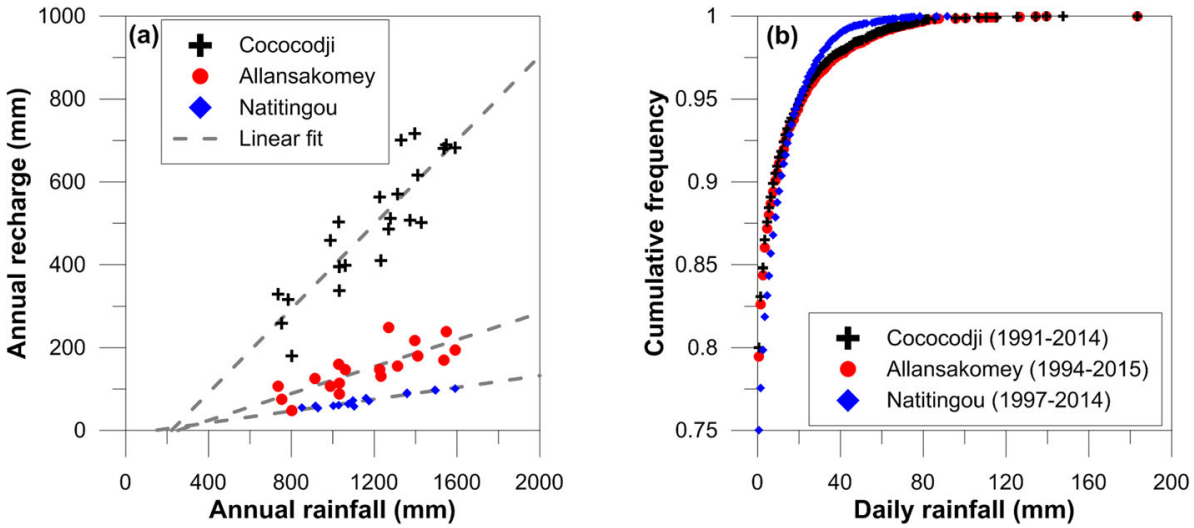
from the modelling of the water table time series (Table 4) are approximate as the sensitivity of the models to the time lag is low (Fig. 4b). This insensitivity arises, in part, from the frequency of the groundwater-level measurements in the current multi-decadal records. However, recently instituted highfrequency (i.e. hourly) monitoring of groundwater levels in Benin (and Uganda) may soon provide improved insight into the time lags between rainfall and recharge as well as daily rainfall thresholds generating recharge in these seasonally humid environments featuring similar hydrogeological environments. Estimated time lags between rainfall and recharge from the analysis of the current long-term records (Table 4) suggest that rainfall is transmitted rapidly $(0-17$ days $)$ through the vadose zone. Further research is nevertheless required to better understand the processes and structures (e.g. macropores) in the unsaturated zone transmitting rain-fed recharge (Owor et al. 2009; Beven and Germann 2013).

\section{Conclusions}

Groundwater recharge, estimated from long-term (1925 years) piezometric records, is shown to be linearly related to annual rainfall in three different hydrogeological environments in seasonally humid Benin; inter-annual changes in groundwater storage correlate well to inter-annual rainfall variability. This rare set of long-term groundwater-level observations from three common hydrogeological environments in West Africa reveals that recharge occurs annually in response to seasonal rainfall (mean of $1200 \mathrm{~mm} \mathrm{year}^{-1}$ and $\sigma=$ $261 \mathrm{~mm} \mathrm{year}^{-1}$ ) but varies substantially in magnitude from $491 \mathrm{~mm} \mathrm{year}^{-1}\left(\sigma=160 \mathrm{~mm}\right.$ year $\left.^{-1}\right)$ in a shallow aquifer of Quaternary sands to $148 \mathrm{~mm}$ year $^{-1}\left(\sigma=55 \mathrm{~mm} \mathrm{year}^{-1}\right)$ in a Mio-Pliocene sandstone aquifer and $51 \mathrm{~mm} \mathrm{year}^{-1}(\sigma=$ $10 \mathrm{~mm}$ year $^{-1}$ ) in a weathered quartzite aquifer. Of significance is that these new estimates, computed via the watertable fluctuation method, are constrained by localised estimates of specific yield. Presented results include the first estimate of recharge to the shallow aquifer in Quaternary Sands in coastal Benin and indicate further that current recharge estimates in the Hydrogeological Map of Benin (Achidi et al. 2012b), in both the Mio-Pliocene sandstone of southern Benin and the Neoproterozoic crystalline rocks of central Benin, are over-estimated. Observed differences in recharge rates and lag times ( $0-17$ days) between groundwater-level response times to rainfall are primarily attributed to lithological controls on the transmission and storage of rain-fed recharge and thickness of the unsaturated zone. Further field research is required to better understand the recharge processes that account for the noted brevity of lag times observed between rainfall and recharge. Fitting of simple scalar models of recharge to the long-term groundwater-level records in each hydrogeological environment suggests that recharge depends on daily rainfall exceeding a threshold ( 5 to $15 \mathrm{~mm} \mathrm{day}^{-1}$ ). As such the results presented here are consistent with a growing body of evidence from Sub-Saharan Africa that indicate that the intensification of rainfall associated with global warming may enhance groundwater recharge.

The robustness of the results of this study is constrained by the representivity of the monitoring sites and frequency of the groundwater level measurements in the multi-decadal records. Further research employing additional monitoring sites, higher frequency observations and complementary techniques (i.e. tracers, numerical modelling) is required to enhance understanding of the recharge processes and controls in seasonally humid environments in the tropics.

Acknowledgements This work has been carried out in the framework of the GRIBA project (Groundwater Resources In Basement rocks of Africa) funded by The African Union, The European Union and the Institut de Recherche pour le Développement (Ref. AURG/098/2012). The content of this paper is the sole responsibility of the authors and can under no circumstances be regarded as reflecting the position of The European Union or Africa Union. Furthermore, we gratefully acknowledge the funding support of PROTOS (http://www.protos.ngo/fr) that make the $\mathrm{PhD}$ work of first-author Kotchoni possible, and the additional financial support of Via Water, a Dutch programme to support innovative water solutions in Africa (http://www.viawater.nl). Co-author Taylor acknowledges support from the UK's NERC-ESRC-DFID UPGro Programme (Refs. NE/L001926/1, NE/M008932/1) and a Senior Fellowship from The Royal Society and Leverhulme Trust (Ref. LT170004).

Open Access This article is distributed under the terms of the Creative Commons Attribution 4.0 International License (http:// creativecommons.org/licenses/by/4.0/), which permits unrestricted use, distribution, and reproduction in any medium, provided you give appropriate credit to the original author(s) and the source, provide a link to the Creative Commons license, and indicate if changes were made.

\section{References}

Achidi JB, Bourguet L, Elsaesser R, Legier A, Paulve E, Tribouillard N (2012a) Evaluation de l'impact d'une baisse de la pluviométrie sur la recharge de l'aquifère du Mio-Pliocene du plateau d'Allada [Evaluation of the impact of a decrease in rainfall on recharge of the Mio-Pliocene aquifer of the Allada plateau]. GIZ Bonn, Germany, $62 \mathrm{pp}$

Achidi JB, Bourguet L, Elsaesser R, Legier A, Paulve E, Tribouillard N (2012b) Carte hydrogéologique du Bénin au 1/500 000 and 1/200 000, notice générale (Hydrogeological map of Benin at 1/500 000 and $1 / 200000$, general notice). GIZ, Bonn, Germany or DGEau, Cotonou, Benin

Allan RP, Soden BJ, John VO, Ingram W, Good P (2010) Current changes in tropical precipitation. Environ Res Lett 5:025205

Beven K, Germann P (2013) Macropores and water flow in soils revisited. Water Resour Res 49:3071-3092. https://doi.org/10. 1002/wrcr.20156

Bonsor HC, and MacDonald AM (2010) Groundwater and climate change in Africa: review of recharge studies. British Geological Survey Internal Report, IR/10/075. BGS, Keyworth, UK, 30 pp

Boucher M, Favreau G, Vouillamoz JM, Nazoumou Y, Legchenko A (2009) Estimating specific yield and transmissivity with magnetic resonance sounding in an unconfined sandstone aquifer (Niger). 
Hydrogeol J 17:1805-1815. https://doi.org/10.1007/s10040-0090447-x

Döll P, Hoffmann-Dobrev H, Portmann FT, Siebert S, Eicker A, Rodell M, Strassberg G, Scanlon BR (2012) Impact of water withdrawals from groundwater and surface water on continental water storage variations. J Geodynam 59:143-156

Favreau G, Cappelaere B, Massuel S, Leblanc M, Boucher M, Boulain N, Leduc C (2009) Land clearing, climate variability, and water resources increase in semiarid Southwest Niger: a review. Water Resour Res 45. https://doi.org/10.1029/2007WR006785

Healy RW, Cook PG (2002) Using groundwater levels to estimate recharge. Hydrogeol J 10:91-109

Ibrahim M, Favreau G, Scanlon BR, Seidel JL, Le Coz M, Demarty J, Cappelaere B (2014) Long-term increase in diffuse groundwater recharge following expansion of rainfed cultivation in the Sahel. West Africa. Hydrogeol J 22:1293-1305. https://doi.org/10.1007/ s10040-014-1143-z

Jasechko S, Taylor RG (2015) Intensive rainfall recharges tropical groundwaters. Environ Res Lett 10:124015. https://doi.org/10. 1088/1748-9326/10/12/124015

Jassas H, Merkel B (2014) Estimating groundwater recharge in the semiarid Al-Khazir Gomal Basin, North Iraq. Water 6:2467-2481. https://doi.org/10.3390/w6082467

Kamagaté B, Séguis L, Favreau G, Seidel JL, Descloitres M, Affaton P (2007) Processus et bilan des flux hydriques d'un bassin versant de milieu tropical de socle au Bénin (Donga, haut Ouémé) [Process and balance of water flows of a basement tropical basin in Benin (Donga, upper Oueme)]. C R Geosci 339:418-429. https://doi.org/ 10.1016/j.crte.2007.04.003

Le Barbé L, Alé G, Millet B, Texier H, Borel Y, Gualde R (1993) Les ressources en eaux superficielles de la République du Bénin, Collection Monographies Hydrologiques $\mathrm{N}^{\circ} 11$ [The surface water of the republic of Benin, Hydrological Monograph no. 11]. Orstom, Paris, $540 \mathrm{pp}$

Legchenko A (2013) Magnetic resonance imaging for groundwater. Wiley, Chichester, UK. https://doi.org/10.1002/9781118649459

Legchenko A, Valla P (2002) A review of the basic principles for proton magnetic resonance sounding measurements. J Appl Geophys 50:319

MacDonald AM, Bonsor HC, Béó D, Taylor RG (2012) Quantitative maps of groundwater resources in Africa. Environ Res Lett 7: 024009. https://doi.org/10.1088/1748-9326/7/2/024009

Mamadou O, Galle S, Cohard JM, Peugeot C, Kounouhewa B, Biron R, Hector B, Zannou AB (2016) Dynamics of water vapor and energy exchanges above two contrasting Sudanian climate ecosystems in northern Benin (West Africa). J Geophys Res-Atmos 121:11269 11286. https://doi.org/10.1002/2016JD024749

Misstear BDR, Brown L, Johnston PM (2009) Estimation of groundwater recharge in a major sand and gravel aquifer in Ireland using multiple approaches. Hydrogeol J 17:693-706. https://doi.org/10.1007/ s10040-008-0376-0

Obuobie E, Diekkrueger B, Agyekum W, Agodzo S (2012) Groundwater level monitoring and recharge estimation in the white Volta River basin of Ghana. J Afr Earth Sci 71-72:80-86. https://doi.org/10. 1016/j.jafrearsci.2012.06.005

Owor M, Taylor RG, Tindimugaya C, Mwesigwa D (2009) Rainfall intensity and groundwater recharge: empirical evidence from the upper Nile Basin. Environ Res Lett 4:035009. https://doi.org/10. 1088/1748-9326/4/3/035009

Scanlon BR, Healy RW, Cook PG (2002) Choosing appropriate techniques for quantifying groundwater recharge. Hydrogeol J 10(18): 39

Séguis L, Kamagaté B, Favreau G, Descloitres M, Seidel JL, Galle S, Peugeot C, Gosset M, Le Barbé L, Malinur F, others (2011) Origins of streamflow in a crystalline basement catchment in a sub-humid Sudanian zone: the Donga basin (Benin, West Africa): inter-annual variability of water budget. J Hydrol 402:1-13

Sibanda T, Nonner JC, Uhlenbrook S (2009) Comparison of groundwater recharge estimation methods for the semi-arid Nyamandhlovu area, Zimbabwe. Hydrogeol J 17:1427-1441. https://doi.org/10.1007/ s10040-009-0445-z

Taylor RG, Howard KWF (1999) The influence of tectonic setting on the hydrological characteristics of deeply weathered terrains: evidence from Uganda. J Hydrol 218:44-71. https://doi.org/10.1016/S00221694(99)00024-4

Taylor RG, Todd MC, Kongola L, Maurice L, Nahozya E, Sanga H, MacDonald AM (2013) Evidence of the dependence of groundwater resources on extreme rainfall in East Africa. Nat Clim Chang 3:374 378. https://doi.org/10.1038/nclimate1731

Totin H (2010) Sensibilité des eaux souterraines du bassin sédimentaire côtier du Bénin à l'évolution du climat et aux modes d'exploitation: stratégies de gestion durable [Groundwater sensitivity in the coastal sedimentary basin in Benin to climate change and exploitation methods: sustainable management strategies]. $\mathrm{PhD}$ Thesis, University of Abomey-Calavi, Bénin, 283 pp

Vouillamoz JM, Sokheng S, Bruyere O, Caron D, Arnout L (2012a) Towards a better estimate of storage properties of aquifer with magnetic resonance sounding. J Hydrol 458-459:51-58. https://doi.org/ 10.1016/j.jhydrol.2012.06.044

Vouillamoz JM, Hoareau J, Grammare M, Caron D, Nandagiri L, Legchenko A (2012b) Quantifying aquifer properties and freshwater resource in coastal barriers: a hydrogeophysical approach applied at Sasihithlu (Karnataka state, India). Hydrol Earth Syst Sci 16:43874400. https://doi.org/10.5194/hess-16-4387-2012

Vouillamoz JM, Lawson FMA, Yalo N, Descloitres M (2014) The use of magnetic resonance sounding for quantifying specific yield and transmissivity in hard rock aquifers: the example of Benin. J Appl Geophys 107:16-24. https://doi.org/10.1016/j.jappgeo.2014.05.012 